Khudolii, O., lermakov, S., Ivashchenko, O., \& Nosko, M. (2020). Strength Abilities: Modeling of Immediate and Delayed Training Effect of Strength Loads in Boys Aged 8 Years. Teoriâ ta Metodika Fizičnogo Vihovannâ, 20(4), 248-255.

https://doi.org/10.17309/tmfv.2020.4.08

ISSN 1993-7989 (print). ISSN 1993-7997 (online)

\title{
STRENGTH ABILITIES: MODELING OF IMMEDIATE AND DELAYED TRAINING EFFECT OF STRENGTH LOADS IN BOYS AGED 8 YEARS
}

\author{
Oleg Khudolii ${ }^{1 \mathrm{ABCD}}$, Sergii Iermakov ${ }^{2 \mathrm{ABCD}}$, Olha Ivashchenko ${ }^{1 \mathrm{ABCD}}$, Mykola Nosko ${ }^{\mathrm{ABCD}}$ \\ ${ }^{1}$ H. S. Skovoroda Kharkiv National Pedagogical University \\ ${ }^{2}$ Gdansk University of Physical Education and Sport \\ ${ }^{3}$ T. H. Shevchenko National University "Chernihiv Colehium" \\ Authors' Contribution: A - Study design; B - Data collection; C - Statistical analysis; D - Manuscript Preparation; E - Funds Collection
}

Corresponding Author: Oleg Khudolii, E-mail: khudoli@hnpu.edu.ua

Accepted for Publication: December 20, 2020

Published: December 25, 2020

DOI: 10.17309/tmfv.2020.4.08

\begin{abstract}
The purpose of the study was to obtain regression models of immediate and delayed training effect of strength loads in boys aged 8 years, based on a full factorial experiment.

Materials and methods. The study participants were 48 boys aged 8 years. The experiment was performed using a $2^{2}$ factorial design. The study materials were processed by the IBM SPSS 22 statistical analysis program. The study examined the impact of four variants of strength load on the immediate (ITE) and the delayed (DTE) training effect of orthogonal strength exercises modes and rest intervals in boys aged 8 years.

Results. The study results show that in the proposed matrix of the $2^{2}$ full factorial design, the chosen step of variation of factors is sufficient to study the influence of different modes of strength exercises on the dynamics of ITE in boys aged 8 years. Based on the data analysis, the study obtained regression models of load for calculating the ITE ITE $_{2}$, and DTE. The obtained regression models make it possible to calculate the number of repetitions and rest interval to achieve the most rational load variant.

Conclusions. The analysis of regression equations shows the interrelation between training effects: ITE $_{1} \rightarrow$ ITE $_{2}$ $\rightarrow$ DTE. The value of ITE ITE $_{2}$, and DTE at station I (exercises to strengthen arms and shoulders) and station II (exercises to strengthen abdominal muscles) depends on the increase in the number of repetitions in a set and the duration of the rest interval. The value of ITE ITE $_{2}$ at station III (exercises to strengthen back muscles) depends on the increase in the number of repetitions in a set and the duration of the rest interval. The value of DTE - on the increase in the number of repetitions in a set and the reduction of the rest interval duration. The value of ITE $\mathrm{E}_{1}$ at station IV (exercises to strengthen leg muscles) depends on the increase in the number of repetitions in a set and the reduction of the rest interval duration. To strengthen the DTE, it is necessary to reduce the number of repetitions in a set and the duration of the rest interval.

Keywords: boys aged 8 years, training effects, strength exercises, combined method of strength development, factorial design.
\end{abstract}

\section{Introduction}

Normalization of physical loads in physical education classes is one of the factors that ensure the effectiveness of schoolchildren's physical education (Ivashchenko, Khudolii, Iermakov, Veremeenko, \& Lopatiev, 2018; Veremeenko, Khudolii, \& Ivashchenko, 2019; Ivashchenko, 2020). Washabaugh, Augenstein, and Krishnan (2020), Benzing, and Schmidt (2019) emphasize the use of dosed efforts in both physical

(C) Khudolii, O., Iermakov, S., Ivashchenko, O., Nosko, M., 2020. education and sports training. Bogdanis, Donti, Papia, Donti, Apostolidis, and Sands (2019), Wertheimer, Antekolovic, and Matkovic (2018) note a positive effect of plyometric loads on the level of motor fitness of both children and adults. The relevance of studying the "dose-effect" (cause-effect) in children's physical activity is indicated by Lovric, Mandic Jelaska, and Bilic (2018), Marttinen, Fredrick III, and Silverman (2018).

Technological approaches to assessing the training effects of strength loads in primary schoolchildren are presented in the studies by Ivashchenko (2020), Ivashchenko, Khudolii, Prusik, and Giovanis (2020), Iermakov, Ivashchenko, 
Khudolii, and Chernenko (2020). One of the technological approaches is the use of pattern recognition methodology in research (Neimark \& Teklina, 2007, 2012; Ivashchenko et al., 2018). Ivashchenko, Khudolii, Iermakov, Chernenko, and Honcharenko (2018) indicate the effectiveness of using factorial designs and discriminant analysis in physical education research.

The importance of developing methodological approaches to normalization and management of training loads in physical education classes in order to improve the effectiveness of teaching is pointed out in the studies by Khudolii, Iermakov, and Bartik (2020), Ivashchenko, Berezhna, and Cieślicka (2020), Ivashchenko and Sirichenko (2020).

Thus, the problem of normalization of strength loads in primary schoolchildren's physical education classes is relevant and requires additional research.

The purpose of the study was to obtain regression models of immediate and delayed training effect of strength loads in boys aged 8 years, based on a full factorial experiment.

\section{Materials and methods}

\section{Study participants}

The study participants were boys aged 8 years $(n=48)$. The children and their parents were fully informed about all the features of the study and gave their consent to participate in the experiment.

\section{Study organization}

To solve the tasks set, theoretical and empirical methods were used: analysis and generalization of scientific and methodological literature; modeling, pedagogical observation and experiment, regression analysis.

Table 1. Factorial design in studying the influence of different modes of the combined method of strength development (variant I) in primary schoolchildren $\left(x_{1}-\right.$ number of repetitions in a set; $x_{2}$ - rest interval, $\mathrm{s}$ )

\begin{tabular}{clcc}
\hline $\begin{array}{c}\text { No. } \\
\text { of strength load } \\
\text { variant }\end{array}$ & \multicolumn{1}{c}{ Method } & $\boldsymbol{x}_{1}$ & $\boldsymbol{x}_{2}$ \\
\hline \multirow{3}{*}{ I } & Dynamic effort method & $3-$ & $30-$ \\
& Maximal effort method & $1-$ & $30-$ \\
& Isometric effort method & $3-$ & $30-$ \\
& Repeated effort method & $6-$ & $30-$ \\
\hline \multirow{3}{*}{ II } & Dynamic effort method & $5+$ & $30-$ \\
& Maximal effort method & $3+$ & $30-$ \\
& Isometric effort method & $5+$ & $30-$ \\
& Repeated effort method & $12+$ & $30-$ \\
\hline \multirow{3}{*}{ III } & Dynamic effort method & $3-$ & $60+$ \\
& Maximal effort method & $1-$ & $60+$ \\
& Isometric effort method & $3-$ & $60+$ \\
& Repeated effort method & $6-$ & $60+$ \\
\hline \multirow{2}{*}{ IV } & Dynamic effort method & $5+$ & $60+$ \\
& Maximal effort method & $3+$ & $60+$ \\
& Isometric effort method & $5+$ & $60+$ \\
& Repeated effort method & $12+$ & $60+$ \\
\hline
\end{tabular}

To determine the dynamics of strength training effects in boys aged 8 years, the study carried out an experiment according to the plan given in Table 1. Variant I of the combined method was used to strengthen arm and shoulder muscles (station I), abdominal muscles (station II), back muscles (station III), and leg muscles (station IV). At each station, the following methods were used: dynamic effort method, maximal effort method, isometric effort method, repeated effort method. The modes of performance for each group, for the indicated stations are given in Table 1 . The study examined the impact of four variants of strength load on the immediate training effect $\left(\mathrm{ITE}_{1}\right)$ after performing exercises at four stations, the immediate training effect $\left(\mathrm{ITE}_{2}\right)$ after training, and the delayed training effect (DTE) 24 hours after training.

At each station, the following exercises were performed:

Station I. Exercises for arm and shoulder muscles.

1. Dynamic effort method. Knee push-ups. The exercise is performed as quickly as possible.

2. Maximal effort method. Weighted push-ups (stuffed ball).

3. Isometric effort method. Knee push-ups. The exercise is performed with two stops and fixation of joint angles $(5 \mathrm{~s})$.

4. Repeated effort method. Knee push-ups.

Station II. Exercises to strengthen abdominal muscles.

1. Dynamic effort method. Sit-ups. The exercise is performed as quickly as possible.

2. Maximal effort method. Hanging 90-degree leg raises on wall bars.

3. Isometric effort method. Decline bench 90-degree leg raises. The exercise is performed with two stops and fixation of joint angles (5s).

4. Repeated effort method. Decline bench leg raises to plow.

Station III. Exercises to strengthen back muscles.

1. Dynamic effort method. Trunk lift. The exercise is performed as quickly as possible.

2. Maximal effort method. Trunk lift on a pommel horse with feet supported under wall bars.

3. Isometric effort method. Trunk lift with two stops and holding each static position for $5 \mathrm{~s}$. The exercise is performed with two stops and fixation of joint angles (5s) (hold positions in the upper point and horizontally).

4. Repeated effort method. The same starting position. Trunk lift.

Station IV. Exercises to strengthen leg muscles.

1. Dynamic effort method. Squats. The exercise is performed as quickly as possible.

2. Maximal effort method. Weighted squats (stuffed ball, dumbbells)

3. Isometric effort method. Weighted squats with stops. The exercise is performed with two stops and fixation of joint angles (5s) $\left(90^{\circ}, 135^{\circ}\right)$.

4. Repeated effort method. Squats.

During the experiment, the study recorded the results of the following tests: 1 . Push-ups. 2 . Speed push-ups, 3 times. 3. Sit-ups in 30 seconds. 4 . Trunk lift in 10 seconds. 5. Standing long jump.

On the first day before the experiment, the study recorded the results of Test 2 "Speed push-ups, 3 times", Test 1 "Push-ups", Test 3 "Sit-ups in 30 seconds", Test 4 "Trunk lift 
in 10 seconds", Test 5 "Standing long jump". After performing the exercises at station I - Tests 2, 1; at station II - Test 3; at station III - Test 4; at station IV - Test 5 . After training - Tests 2, 1, 3, 4. Twenty-four hours after training - Tests $2,1,3,4,5$. The dynamics of test results was determined as a percentage relative to the initial level.

\section{Statistical analysis}

The study materials were processed using the IBM SPSS 22 statistical analysis program. The Yates' algorithm was used to calculate the regression coefficients.

The study protocol was approved by the Ethical Committee of H. S. Skovoroda Kharkiv National Pedagogical University.

\section{Results}

Tables 2-7 show the results of the $2^{2}$ full factorial design. The study examined the impact of four variants of strength load on the ITE 1 after performing exercises at four stations, the $\mathrm{ITE}_{2}$ after training, and the DTE 24 hours after training.

The results of analysis of the immediate training effect $\left(\mathrm{ITE}_{1}\right)$ after performing exercises at four stations: station 1 "Exercises to strengthen arms and shoulders"; station II "Exercises to strengthen abdominal muscles"; station III "Exercises to strengthen back muscles"; station IV "Exercises to strengthen leg muscles" are given below (see Tables 2-3).

The analysis of the regression equations given in Table 2 made it possible to determine the influence of strength loads on the immediate training effect $\left(\mathrm{ITE}_{1}\right)$ of different modes of exercises in boys aged 8 years. After training at stations I-IV, the following data were obtained:

- $\quad$ after training at station I - exercises to strengthen arms

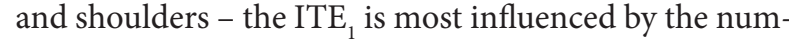
ber of repetitions in a set $\left(x_{1}\right)$ (exercise No. 1) and the rest interval $\left(x_{2}\right)$ (exercise No. 2). To strengthen the ITE $\mathrm{I}_{1}$, it is necessary to increase the number of repetitions in a set and the duration of the rest interval;

- after training at station II - exercises to strengthen abdominal muscles - the ITE 1 is most influenced by the rest interval $\left(x_{2}\right)$, the number of repetitions in a set $\left(x_{1}\right)$, and the interaction between the number of repetitions in a set and the rest interval $\left(x_{1} x_{2}\right)$. To strengthen the ITE , it is necessary to increase the number of repetitions in a set and the duration of the rest interval;

- $\quad$ after training at station III - exercises to strengthen back

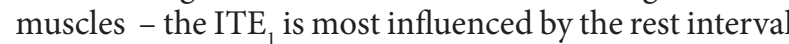
$\left(x_{2}\right)$, the interaction between the number of repetitions in a set and the rest interval $\left(x_{1} x_{2}\right)$, and the number of repetitions in a set $\left(x_{1}\right)$. To strengthen the ITE, it is necessary to increase the number of repetitions in a set and the duration of the rest interval;

- $\quad$ after training at station IV - exercises to strengthen leg muscles - the ITE $\mathrm{I}_{1}$ is most influenced by the rest interval $\left(x_{2}\right)$, the interaction between the number of repetitions in a set and the rest interval $\left(x_{1} x_{2}\right)$, and the number of repetitions in a set $\left(x_{1}\right)$. To strengthen the ITE, it is necessary to increase the number of repetitions in a set and reduce the duration of the rest interval.

The analysis of variance given in Table 3 made it possible to determine the percentage influence of the factors on the immediate training effect (ITE 1 ) of different modes of exer-

Table 2. Models of influence of different strength training modes on the change in the immediate training effect (ITE $)_{1}$ in boys aged 8 years $(n=40)\left(x_{1}\right.$ - amount of training, $x_{2}$ - rest interval). The first variant of the combined method of strength development.

\begin{tabular}{llll}
\hline Place of training & \multicolumn{1}{c}{ Test } & Conditions of recording & Regression equations \\
\hline Station I & No. 1 "Push-ups" & after performing the exercises & $\mathrm{Y}=90.113-2.998 x_{1}-1.168 x_{2}-0.967 x_{1} x_{2}$ \\
Station II & No. 2 "Speed push-ups, 3 times" & after performing the exercises & $\mathrm{Y}=104.660+2.655 x_{1}+3.315 x_{2}-1.240 x_{1} x_{2}$ \\
Station III & No. "S "Trunk lift in 10 seconds" & after performing the exercises & $\mathrm{Y}=93.943-0.918 x_{1}-1.958 x_{2}+0.963 x_{1} x_{2}$ \\
Station IV & No. 5 "Standing long jump" & after performing the exercises & $\mathrm{Y}=98.768-0.078 x_{1}+1.238 x_{2}+0.392 x_{1} x_{2}$ \\
\hline
\end{tabular}

Table 3. Results of the analysis of variance for the $2^{2} \mathrm{FFE}$ in studying the influence of different strength training modes on the change in the immediate training effect $\left(\mathrm{ITE}_{1}\right)$ in boys aged 8 years $(\mathrm{n}=40)\left(x_{1}-\right.$ amount of training, $x_{2}-$ rest interval). The first variant of the combined method of strength development.

\begin{tabular}{|c|c|c|c|c|c|}
\hline \multirow{2}{*}{ Place of training } & \multirow{2}{*}{ Test } & \multirow{2}{*}{ Conditions of recording } & \multicolumn{3}{|c|}{ Ratio of mean squares } \\
\hline & & & $x_{1}$ & $x_{2}$ & $x_{1} x_{2}$ \\
\hline \multirow[b]{2}{*}{ Station I } & No. 1 "Push-ups" & after performing the exercises & 79.6 & 12.0 & 8.4 \\
\hline & No. 2 "Speed push-ups, 3 times" & after performing the exercises & 36.0 & 56.1 & 7.9 \\
\hline Station II & No. 3 "Sit-ups in 30 seconds" & after performing the exercises & 21.8 & 66.4 & 11.8 \\
\hline Station III & No. 4 "Trunk lift in 10 seconds" & after performing the exercises & 15 & 68.4 & 16.6 \\
\hline Station IV & No. 5 "Standing long jump" & after performing the exercises & 0.35 & 90.5 & 9.15 \\
\hline
\end{tabular}


Table 4. Models of influence of different strength training modes on the change in the immediate training effect (ITE $)_{2}$ in boys aged 8 years $(n=40)\left(x_{1}\right.$ - amount of training, $x_{2}$ - rest interval). The first variant of the combined method of strength development. Comprehensive strength development of arm, abdominal, back, and leg muscles.

\begin{tabular}{ll}
\hline \multicolumn{1}{c}{ Test } & \multicolumn{1}{c}{ Regression equations } \\
\hline No. 1 "Push-ups" & $\mathrm{Y}=87.790-0.740 x_{1}-0.1 x_{2}-2.1 x_{1} x_{2}$ \\
No. 2 "Speed push-ups, 3 times" & $\mathrm{Y}=106.108+0.877 x_{1}+1.258 x_{2}+0.068 x_{1} x_{2}$ \\
No. 3 "Sit-ups in 30 seconds" & $\mathrm{Y}=91.698+0.968 x_{1}-2.258 x_{2}-0.627 x_{1} x_{2}$ \\
No. 4 "Trunk lift in 10 seconds" & $\mathrm{Y}=92.875-0.395 x_{1}-1.465 x_{2}+0.265 x_{1} x_{2}$ \\
No. 5 "Standing long jump" & $\mathrm{Y}=98.985+0.095 x_{1}-0.19 x_{2}+0.1 x_{1} x_{2}$ \\
\hline
\end{tabular}

cises in boys aged 8 years. After training at stations I-IV, the following data were obtained:

- $\quad$ after training at station I - exercises to strengthen arms

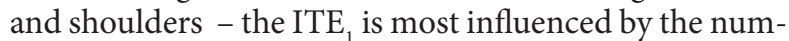
ber of repetitions in a set $\left(x_{1}\right)-79.6 \%$ (exercise No. 1) and the rest interval $\left(x_{2}\right)-56.1 \%$;

- after training at station II - exercises to strengthen abdominal muscles - the ITE is most influenced by the rest interval $\left(x_{2}\right)-66.4 \%$;

- $\quad$ after training at station III - exercises to strengthen back muscles - the ITE is most influenced by the rest interval $\left(x_{2}\right)-68.4 \%$;

- after training at station IV - exercises to strengthen leg muscles - the ITE is most influenced by the rest interval $\left(x_{2}\right)-90.5 \%$.

The data of analysis of the immediate training effect (ITE ${ }_{2}$ ) after training are given in Tables 4-5.

The analysis of the regression equations given in Table 4 made it possible to determine the influence of strength loads on the immediate training effect $\left(\mathrm{ITE}_{2}\right)$ of different modes of exercises in boys aged 8 years. After training, the following data were obtained:

- $\quad$ exercises to strengthen arms and shoulders - the $\mathrm{ITE}_{2}$ is most influenced by the interaction between the number of repetitions in a set and the rest interval $\left(x_{1} x_{2}\right)($ exercise No. 1) and the rest interval $\left(x_{2}\right)$ (exercise No. 2). To strengthen the $\mathrm{ITE}_{2}$, it is necessary to increase the number of repetitions in a set and the duration of the rest interval;

- $\quad$ exercises to strengthen abdominal muscles - the $\mathrm{ITE}_{2}$ is most influenced by the rest interval $\left(x_{2}\right)$, the number of repetitions in a set $\left(x_{1}\right)$, and the interaction between the number of repetitions in a set and the rest interval $\left(x_{1} x_{2}\right)$. To strengthen the $\mathrm{ITE}_{2}$, it is necessary to increase the number of repetitions in a set and the duration of the rest interval;

- $\quad$ exercises to strengthen back muscles - the $\mathrm{ITE}_{2}$ is most influenced by the rest interval $\left(x_{2}\right)$, the number of repetitions in a set $\left(x_{1}\right)$, and the interaction between the number of repetitions in a set and the rest interval $\left(x_{1} x_{2}\right)$. To strengthen the ITE, it is necessary to increase the number of repetitions in a set and the duration of the rest interval;

- exercises to strengthen leg muscles - the $\mathrm{ITE}_{2}$ is most influenced by the rest interval $\left(x_{2}\right)$, the interaction between the number of repetitions in a set and the rest interval $\left(x_{1} x_{2}\right)$, and the number of repetitions in a set $\left(x_{1}\right)$. To strengthen the ITE, it is necessary to reduce the number of repetitions in a set and the duration of the rest interval.
The analysis of variance given in Table 5 made it possible to determine the percentage influence of the factors on the immediate training effect $\left(\mathrm{ITE}_{2}\right)$ of different modes of exercises in boys aged 8 years. After training, the following data were obtained:

- $\quad$ exercises to strengthen arms and shoulders - the $\mathrm{ITE}_{2}$ is most influenced by the interaction between the number of repetitions in a set and the rest interval $\left(x_{1} x_{2}\right)-88.8 \%$ (exercise No. 1) and the rest interval $\left(x_{2}\right)-67.1 \%$;

- $\quad$ exercises to strengthen abdominal muscles - the ITE is most influenced by the rest interval $\left(x_{2}\right)-79.3 \%$;

- exercises to strengthen back muscles - the ITE is most influenced by the rest interval $\left(x_{2}\right)-90.5 \%$;

- $\quad$ exercises to strengthen leg muscles - the ITE is most influenced by the rest interval $\left(x_{2}\right)-65.5 \%$.

The results of analysis of the delayed training effect (DTE) 24 hours after training are given in Tables 6-7.

Table 5. Results of the analysis of variance for the $2^{2} \mathrm{FFE}$ in studying the influence of different strength training modes on the change in the immediate training effect $\left(\mathrm{ITE}_{2}\right)$ in boys aged 8 years $(\mathrm{n}=40)\left(x_{1}\right.$ - amount of training, $x_{2}$ - rest interval). The first variant of the combined method of strength development. Comprehensive strength development of arm, abdominal, back, and leg muscles.

\begin{tabular}{lccc}
\hline \multicolumn{1}{c}{ Test } & \multicolumn{3}{c}{ Ratio of mean squares } \\
\cline { 2 - 4 } & \multicolumn{1}{c}{$\boldsymbol{x}_{\mathbf{1}}$} & \multicolumn{1}{c}{$\boldsymbol{x}_{\mathbf{2}}$} & $\boldsymbol{x}_{\mathbf{1}} \boldsymbol{x}_{\mathbf{2}}$ \\
\hline No. 1 "Push-ups" & 11 & 0.2 & 88.8 \\
No. 2 "Speed push-ups, 3 times" & 32.7 & 67.1 & 0.2 \\
No. 3 "Sit-ups in 30 seconds" & 14.6 & 79.3 & 6.1 \\
No. 4 “Trunk lift in 10 seconds" & 6.6 & 90.5 & 2.9 \\
No. 5 "Standing long jump" & 16.4 & 65.5 & 18.1 \\
\hline
\end{tabular}

The analysis of the regression equations given in Table 6 made it possible to determine the influence of strength loads on the delayed training effect (DTE) of different modes of exercises in boys aged 8 years. 24 hours after training, the following data were obtained:

- $\quad$ exercises to strengthen arms and shoulders - the DTE is most influenced by the number of repetitions in a set $\left(x_{1}\right)$, the rest interval $\left(x_{2}\right)$, the interaction between the number of repetitions in a set and the rest interval $\left(x_{1} x_{2}\right)$ (exercise No. 1), and the interaction between the number 
Table 6. Models of influence of different strength training modes on the change in the delayed training effect (DTE) in boys aged 8 years $(n=40)\left(x_{1}\right.$ - amount of training, $x_{2}$ - rest interval). The first variant of the combined method of strength development. Comprehensive strength development of arm, abdominal, back, and leg muscles.

\begin{tabular}{ll}
\hline \multicolumn{1}{c}{ Test } & \multicolumn{1}{c}{ Regression equations } \\
\hline No. 1 "Push-ups" & $\mathrm{Y}=96.785+2.195 x_{1}-1.315 x_{2}-1.095 x_{1} x_{2}$ \\
No. 2 "Speed push-ups, 3 times" & $\mathrm{Y}=103.99-0.59 x_{1}+0.475 x_{2}-1.275 x_{1} x_{2}$ \\
No. 3 "Sit-ups in 30 seconds" & $\mathrm{Y}=95.413+0.092 x_{1}+0.232 x_{2}-0.278 x_{1} x_{2}$ \\
No. 4 "Trunk lift in 10 seconds" & $\mathrm{Y}=96.23-0.07 x_{1}+1.505 x_{2}+0.015 x_{1} x_{2}$ \\
No. 5 "Standing long jump" & $\mathrm{Y}=99.115+1.765 x_{1}+0.81 x_{2}-1.73 x_{1} x_{2}$ \\
\hline
\end{tabular}

Table 7. Results of the analysis of variance for the $2^{2} \mathrm{FFE}$ in studying the influence of different strength training modes on the change in the delayed training effect (DTE) in boys aged 8 years $(n=40)\left(x_{1}\right.$ - amount of training, $x_{2}-$ rest interval). The first variant of the combined method of strength development. Comprehensive strength development of arm, abdominal, back, and leg muscles.

\begin{tabular}{lccc}
\hline \multirow{2}{*}{ Test } & \multicolumn{3}{c}{ Ratio of mean squares } \\
\cline { 2 - 4 } & $\boldsymbol{x}_{\mathbf{1}}$ & $\boldsymbol{x}_{2}$ & $\boldsymbol{x}_{\mathbf{1}} \boldsymbol{x}_{2}$ \\
\hline No. 1 "Push-ups" & 62.2 & 22.3 & 15.5 \\
No. 2 "Speed push-ups, 3 times" & 15.8 & 10.3 & 73.9 \\
No. 3 "Sit-ups in 30 seconds" & 6.1 & 38.7 & 55.2 \\
No. 4 “Trunk lift in 10 seconds" & 0.2 & 99.8 & 0 \\
No. 5 "Standing long jump" & 46.1 & 9.7 & 44.2 \\
\hline
\end{tabular}

of repetitions in a set and the rest interval $\left(x_{1} x_{2}\right)$ (exercise No. 2). To strengthen the DTE, it is necessary to increase the number of repetitions in a set and the duration of the rest interval;

- $\quad$ exercises to strengthen abdominal muscles - the DTE is most influenced by the interaction between the number of repetitions in a set and the rest interval $\left(x_{1} x_{2}\right)$, the rest interval $\left(x_{2}\right)$, the number of repetitions in a set $\left(x_{1}\right)$. To strengthen the DTE, it is necessary to increase the number of repetitions in a set and the duration of the rest interval;

- $\quad$ exercises to strengthen back muscles - the DTE is most influenced by the rest interval $\left(x_{2}\right)$, the interaction between the number of repetitions in a set and the rest interval $\left(x_{1} x_{2}\right)$, and the number of repetitions in a set $\left(x_{1}\right)$. To strengthen the DTE, it is necessary to increase the number of repetitions in a set and reduce the duration of the rest interval;

- $\quad$ exercises to strengthen leg muscles - the DTE is most influenced by the number of repetitions in a set $\left(x_{1}\right)$, the interaction between the number of repetitions in a set and the rest interval $\left(x_{1} x_{2}\right)$, and the rest interval $\left(x_{2}\right)$. To strengthen the DTE, it is necessary to reduce the number of repetitions in a set and the duration of the rest interval. The analysis of variance given in Table 7 made it possible to determine the percentage influence of the factors on the delayed training effect (DTE) of different modes of exercises in boys aged 8 years. 24 hours after training, the following data were obtained:
- $\quad$ exercises to strengthen arms and shoulders - the DTE is most influenced by the number of repetitions in a set $\left(x_{1}\right)-62.2 \%$ (exercise No. 1) and the interaction between the number of repetitions in a set and the rest interval $\left(x_{1} x_{2}\right)-73.9 \%$;

- $\quad$ exercises to strengthen abdominal muscles - the DTE is most influenced by the interaction between the number of repetitions in a set and the rest interval $\left(x_{1} x_{2}\right)-55.2 \%$;

- $\quad$ exercises to strengthen back muscles - the DTE is most influenced by the rest interval $\left(x_{2}\right)-99.8 \%$;

- exercises to strengthen leg muscles - the DTE is most influenced by the number of repetitions in a set $\left(x_{1}\right)-$ $46.1 \%$ and the interaction between the number of repetitions in a set and the rest interval $\left(x_{1} x_{2}\right)-44.2 \%$.

\section{Discussion}

The study assumed that a full factorial experiment would allow to determine the influence of strength loads on the immediate training effect (ITE) and the delayed training effect (DTE) of different modes of exercises in boys aged 8 years. The study results show that in the proposed matrix of the $2^{2}$ full factorial design, the chosen step of variation of factors is sufficient to study the influence of different modes of strength exercises on the dynamics of ITE in boys aged 8 years (Table 1). Based on the data analysis, the study obtained regression models of load for calculating the $\mathrm{ITE}_{1}$ (Table 2), $\mathrm{ITE}_{2}$ (Table 4), and DTE (Table 6).

The studies by Iermakov, Ivashchenko, Khudolii, and Chernenko (2020), Ivashchenko, Khudolii, Prusik, and Giovanis (2020), Ivashchenko, Nosko, and Ferents (2019) substantiated the influence of different load variants on the dynamics of the immediate and delayed training effect on the basis of discriminant analysis. Iermakov, Ivashchenko, Khudolii, and Chernenko (2020) found the interrelation of training effects. The obtained data indicate that each of the variants of strength load can be effectively used depending on the educational tasks of both one and a series of physical education classes, and also show that the ITE and DTE of strength exercises depend on the initial level of fitness and the total amount of strength exercises in a physical education class. Ivashchenko, Khudolii, Prusik, and Giovanis (2020) point out that in the first variant of strength load, the greatest contribution to the dynamics of training effects is made by training at the first station "exercises to strengthen arms and shoulders"; in the second variant, the greatest contribution to the dynamics of training effects is made by training at the third station "exercises to strengthen back muscles"; 
in the third variant, the greatest contribution to the dynamics of training effects is made by training at the first station "exercises to strengthen arms and shoulders" and the third station "exercises to strengthen back muscles"; in the fourth variant, the greatest contribution to the dynamics of the ITE is made by training at the first "exercises to strengthen arms and shoulders" and the third "exercises to strengthen back muscles" stations; the most significant changes in the DTE are connected with training at the fourth station "exercises to strengthen leg muscles".

The obtained regression models make it possible to calculate the number of repetitions and rest interval to achieve the most rational load variant. These data supplement the results presented in the studies by Iermakov, Ivashchenko, Khudolii, and Chernenko (2020), Ivashchenko, Khudolii, Prusik, and Giovanis (2020) and form a methodology for studying training loads, which differs from the methods used in the studies by Arazi et al. (2012), Ratamess et al. (2012), Miranda et al. (2010) in that research is conducted using an active $2^{\mathrm{k}} \mathrm{FFE}$ and materials are processed with the help of regression and discriminant analysis.

The results supplement the information of Ivashchenko and Cieślicka (2017), Cieślicka and Ivashchenko (2017) about the effectiveness of using factorial designs in studying training effects of strength loads in children; that of Ivashchenko, Khudolii, Iermakov, Chernenko and Honcharenko (2018), Marchenko and Kovalenko (2020) about the reliability of obtained regression equations for modeling the process of motor skills and motor abilities development in schoolchildren.

The effectiveness of using a $2^{\mathrm{k}}$ full factorial experiment is confirmed by data of Correa, Grima, and Tort-Martorell (2009, 2012), Ivashchenko, Nosko, and Ferents (2019). The main purpose of designs is to neutralize the influence of unknown factors, the authors recommend using designs with three and four factors. The results of presented research (Tables 2-7) show the effectiveness of using a $2^{2} \mathrm{FFE}$ in studying the ITE of strength loads in boys aged 8 years.

The obtained results specify the conceptual approaches to experiment planning in studying the effectiveness of children's physical education, factorial designs are an objective tool for obtaining data to calculate regression models of training effects in children (Khudolii, Ivashchenko, Iermakov, Nosko, \& Marchenko, 2019; Khudolii, 2019; Ivashchenko, 2020).

In addition, strength training of schoolchildren is considered as a necessary condition of the educational process (Kapkan, Khudolii, \& Bartik, 2019a,b). Based on the analysis of regression equations, it is possible to choose a load by focus, based on discriminant analysis - to choose a total load.

\section{Conclusions}

The study results show that in the proposed matrix of the 22 full factorial design, the chosen step of variation of factors is sufficient to study the influence of different modes of strength exercises on the dynamics of ITE in boys aged 8 years. Based on the data analysis, the study obtained regression models of load for calculating the $\mathrm{ITE}_{1}, \mathrm{ITE}_{2}$, and DTE. The obtained regression models make it possible to calculate the number of repetitions and rest interval to achieve the most rational load variant.
The analysis of regression equations shows the interrelation between training effects: ITE $_{1}->\mathrm{ITE}_{2}->$ DTE. The value of ITE ITE $_{2}$, and DTE at station I (exercises to strengthen arms and shoulders) and station II (exercises to strengthen abdominal muscles) depends on the increase in the number of repetitions in a set and the duration of the rest interval. The value of ITE, ITE $_{2}$ at station III (exercises to strengthen back muscles) depends on the increase in the number of repetitions in a set and the duration of the rest interval. The value of DTE - on the increase in the number of repetitions in a set and the reduction of the rest interval duration. The value of ITE $_{1}$ at station IV (exercises to strengthen leg muscles) depends on the increase in the number of repetitions in a set and the reduction of the rest interval duration. To strengthen the DTE, it is necessary to reduce the number of repetitions in a set and the duration of the rest interval.

\section{Acknowledgement}

The study was carried out in accordance with the plan of research work of the Department of Theory and Methodology of Physical Education of H. S. Skovoroda Kharkiv National Pedagogical University.

\section{Conflict of interest}

The authors declare no conflict of interest.

\section{References}

Ivashchenko, O., Khudolii, O., Iermakov, S., Veremeenko, V., \& Lopatiev, A. (2018). Power abilities: recognition of the level of development in girls aged 12-14 years. Pedagogics, Psychology, Medical-Biological Problems of Physical Training and Sports, 22(3), 142-148. https://doi.org/10.15561/18189172.2018.0305

Veremeenko, V., Khudolii, O., \& Ivashchenko, O. (2019). Motor abilities: methods of strength and strength endurance development in middle-school-aged boys in a 4-week physical training cycle. Pedagogics, Psychology, MedicalBiological Problems of Physical Training and Sports, 23(2), 102-111. https://doi.org/10.15561/18189172.2019.0208

Washabaugh, E. P., Augenstein, T. E., \& Krishnan, C. (2020). Functional resistance training during walking: Mode of application differentially affects gait biomechanics and muscle activation patterns. Gait \& Posture, 75, 129-136. https://doi.org/10.1016/j.gaitpost.2019.10.024

Benzing, V., \& Schmidt, M. (2019). The effect of exergaming on executive functions in children with ADHD: A randomized clinical trial. Scandinavian Journal of Medicine \& Science in Sports, 29(8), 1243-1253. https://doi.org/10.1111/sms.13446

Bogdanis, G. C., Donti, O., Papia, A., Donti, A., Apostolidis, N., \& Sands, W. A. (2019). Effect of Plyometric Training on Jumping, Sprinting and Change of Direction Speed in Child Female Athletes. Sports, 7(5), 116. https://doi.org/10.3390/sports7050116

Wertheimer, V., Antekolovic, L., \& Matkovic, B. R. (2018). Muscle damage indicators after land and aquatic plyometric training programmes. Montenegrin Journal of 
Sports Science and Medicine, 7(1), 13-19.

https://doi.org/10.26773/mjssm.180302

Lovric, F., Mandic Jelaska, P., \& Bilic, Z. (2018). Physical activity cannot be treated as a predictor of anthropological status among six-year-old children. Montenegrin Journal of Sports Science and Medicine, 7(1), 53-57. https://doi.org/10.26773/mjssm.180307

Marttinen, R., N. Fredrick, R., III, \& Silverman, S. S. (2018). Middle school students' free-living physical activity on physical education days, non-physical education days, and weekends. Montenegrin Journal of Sports Science and Medicine, 7(1), 5-12.

https://doi.org/10.26773/mjssm.180301

Ivashchenko, O. (2020). Research Program: Modeling of Motor Abilities Development and Teaching of Schoolchildren. Teoriâ ta Metodika Fizičnogo Vihovannâ, 20(1), 32-41. https://doi.org/10.17309/tmfv.2020.1.05

Iermakov, S., Ivashchenko, O., Khudolii, O., \& Chernenko, S. (2020). Strength Abilities: Assessment of Training Effects of Strength Loads in Boys Aged 8 Years. Teoriâ ta Metodika Fizičnogo Vihovannâ, 20(3), 174-181. https://doi.org/10.17309/tmfv.2020.3.07

Ivashchenko, O., Khudolii, O., Prusik, K., \& Giovanis, V. (2020). Strength Abilities: Immediate and Delayed Training Effects of Orthogonal Modes of Strength Training in Boys Aged 8 Years. Teoriâ ta Metodika Fizičnogo Vihovannâ, 20(2), 109-116. https://doi.org/10.17309/tmfv.2020.2.07

Neimark, Y.I., \& Teklina, L.G. (2007). Planirovanie eksperimenta pri issledovanii konkretnykh dinamicheskikh sistem metodami raspoznavaniia obrazov. Matematicheskie metody raspoznavaniia obrazov, 13(1), 194-196

Neimark, Y. I., \& Teklina, L. G. (2012). On possibilities of using pattern recognition methods to study mathematical models. Pattern Recognition and Image Analysis, 22(1), 144-149. https://doi.org/10.1134/S1054661812010282

Ivashchenko, O., Khudolii, O., Iermakov, S., Chernenko, S., \& Honcharenko, O. (2018). Full factorial experiment and discriminant analysis in determining peculiarities of motor skills development in boys aged 9. Journal of Physical Education and Sport, 18(4s), 1958-1965. https://doi.org/10.7752/jpes.2018.s4289

Khudolii, O., Iermakov, S., \& Bartik, P. (2020). Didactics: Methodological Basis of Motor Learning in Children and Adolescents. Journal of Learning Theory and Methodology, 1(1), 5-13. https://doi.org/10.17309/jltm.2020.1.01

Ivashchenko, O., Berezhna, H., \& Cieślicka, M. (2020). Motor Skills in the Structure of Physical Fitness of 7-Year-Old Boys. Journal of Learning Theory and Methodology, 1(1), 14-19. https://doi.org/10.17309/jltm.2020.1.02

Ivashchenko, O., \& Sirichenko, D. (2020). Structure of Motor Fitness of 7-Year-Old Girls. Journal of Learning Theory and Methodology, 1(1), 20-25. https://doi.org/10.17309/jltm.2020.1.03

Arazi, H., Mirzaei, B., Sangdevini, M., \& Abadi, M. (2012). An Interaction between Exercise Order and Rest Interval during Lower-Body Resistance Exercise. Baltic Journal of
Health and Physical Activity, 4(2). https://doi.org/10.2478/v10131-012-0008-x

Ratamess, N. A., Chiarello, C. M., Sacco, A. J., Hoffman, J. R., Faigenbaum, A. D., Ross, R. E., \& Kang, J. (2012). The effects of rest interval length manipulation of the first upper-body resistance exercise in sequence on acute performance of subsequent exercises in men and women. Journal of Strength and Conditioning Research, 26(11), 2929-2938. https://doi.org/10.1519/JSC.0b013e318270fcf0

Miranda, H., Simão, R., Dos Santos Vigário, P., De Salles, B. F., Pacheco, M. T. T., \& Willardson, J. M. (2010). Exercise order interacts with rest interval during upper-body resistance exercise. Journal of Strength and Conditioning Research, 24(6), 1573-1577. https://doi.org/10.1519/JSC.0b013e3181d8ea61

Ivashchenko, O., \& Cieślicka, M. (2017). Features of evaluations of power loadsin boys 7 years old. Journal of Education, Health and Sport, 7(1), 175-183. http://dx.doi.org/10.5281/zenodo.249184

Cieślicka, M., \& Ivashchenko, O. (2017). Features of formation of the cumulative effect of power loads in boys 7 years old. Journal of Education, Health and Sport, 7(1), 198-208. https://doi.org/10.5281/zenodo.250599

Marchenko, S., \& Kovalenko, K. (2020). Optimization of Teaching Boys Aged 10 Mae-Geri (Front Kick) Technique in Kyokushin Karate. Journal of Learning Theory and Methodology, 1(1), 33-39. https://doi.org/10.17309/jltm.2020.1.05

Correa, A. A., Grima, P., \& Tort-Martorell, X. (2009). Experimentation order with good properties for $2^{\mathrm{k}}$ factorial designs. Journal of Applied Statistics, 36(7), 743754. https://doi.org/10.1080/02664760802499337

Correa, A. A., Grima, P., \& Tort-Martorell, X. (2012). Experimentation order in factorial designs: new findings. Journal of Applied Statistics, 39(7), 1577-1591. https://doi.org/10.1080/02664763.2012.661706

Khudolii, O. (2019). Research Program: Modeling of Young Gymnasts' Training Process. Teoriâ ta Metodika Fizičnogo Vihovannâ, 19(4), 168-178. https://doi.org/10.17309/tmfv.2019.4.02

Ivashchenko, O., Nosko, Y., \& Ferents, V. (2019). Strength Abilities: Dynamics of Training Effect of Strength Exercises in Girls Aged 9. Teorîa ta Metodika Fizičnogo Vihovannâ, 19(4), 200-208. https://doi.org/10.17309/tmfv.2019.4.06

Khudolii, O., Ivashchenko, O., Iermakov, S., Nosko, Y., \& Marchenko, S. (2019). Strength Abilities: Estimation of Immediate Training Effect of Strength Loads in Girls Aged 7 Years. Teoriâ ta Metodika Fizičnogo Vihovannâ, 19(2), 98-104. https://doi.org/10.17309/tmfv.2019.2.06

Kapkan, O., Khudolii, O., \& Bartik, P. (2019a). Pattern Recognition: Motor Skills Development in Girls Aged 15. Teoriâ ta Metodika Fizičnogo Vihovannâ, 19(1), 44-52. https://doi.org/10.17309/tmfv.2019.1.06

Kapkan, O., Khudolii, O., \& Bartik, P. (2019b). Motor Skills Development: Optimization of Teaching Boys Aged 14. Teoriâ ta Metodika Fizičnogo Vihovannâ, 19(3), 148155. https://doi.org/10.17309/tmfv.2019.3.06 


\title{
СИЛОВІ ЗДІБНОСТІ: МОДЕЛЮВАННЯ ТЕРМІНОВОГО І ВІДСТАВЛЕНОГО ТРЕНУВАЛЬНОГО ЕФЕКТУ СИЛОВИХ НАВАНТАЖЕНЬ У ХЛОПЦІВ 8 РОКІВ
}

\author{
Олег Худолій ${ }^{1 A B C D}$, Сергій Єрмаков ${ }^{2 A B C D}$, Ольга Іващенко ${ }^{1 A B C D}$, Микола Носко \\ ${ }^{1}$ Харківський національний педагогічний університет імені Г. С. Сковороди \\ ${ }^{2}$ Гданський університет фізичного виховання і спорту \\ ${ }^{3}$ Національний університет «Чернігівський колегіум» імені Т. Г. Шевченка
}

Авторський вклад: А - дизайн дослідження; В - збір даних; C - статаналіз; D - підготовка рукопису; Е - збір коштів

Реферат. Стаття: 8 с., 6 табл., 30 джерел

Мета дослідження - на основі повного факторного експерименту отримати регресійні моделі термінового і відставленого тренувального ефекту силових навантажень у хлопців 8 років.

Матеріали і методи. У дослідженні прийняли участь 48 хлопців 8 років. Експеримент був проведений за планом факторного експерименту $2^{2}$. Матеріали дослідження опрацьовані в програмі статистичного аналізу IBM SPSS 22. Вивчався вплив чотирьох варінтив силового навантаження на терміновий (ТTE) і відставлений (ВТЕ) тренувальний ефект ортогональних режимів виконання силових вправ та інтервалів відпочинку у хлопчиків 8 років.

Результати. Результати дослідження свідчать, що у запропонованій матриці плану повного факторного експерименту типа $2^{2}$ вибраний крок варіювання факторів $є$ достатнім для вивчення впливу різних режимів виконання силових вправ на динаміку TTE у хлопчиків 8 років. На основі аналізу даних отримані регресійні моделі навантаження для розрахунку $\mathrm{TTE}_{1}$, $\mathrm{TTE}_{2}$ та ВТЕ. Отримані регресійні моделі дають змогу розрахувати кількість повторень та інтервал відпочин- ку для досягнення найбільш раціонального варіанта навантаження.

Висновки. Аналіз рівнянь регресії вказує на взамозв'язок тренувальних ефектів: $\mathrm{TTE}_{1} \rightarrow \mathrm{TTE}_{2} \rightarrow$ BTE. Величина TTE, $\mathrm{TTE}_{2}$, ВТE на I станції (вправи для розвитку сили рук і плечового поясу) та II станції (вправи для розвитку сили м'язів черевного пресу) залежить від збільшення кількості повторень у підході й тривалості інтервалу відпочинку. Величина TTE TTE, на III станції (вправи для розвитку сили м'язів спини) - від збільшення кількості повторень у підході й тривалості інтервалу відпочинку. Величина ВТЕ - від збільшення кількості повторень у підході й зменшення тривалості інтервалу відпочинку. Величина TTE станції (вправи для розвитку сили м'язів ніг) залежить від збільшення кількості повторень у підході й зменшення тривалості інтервалу відпочинку. Для підсилення ВТЕ необхідно зменшити кількість повторень у підході й зменшити тривалість інтервалу відпочинку.

Ключові слова: хлопців 8 років, тренувальні ефекти, силові вправи, комбінований метод розвитку сили, план факторного експерименту.

\section{Information about the authors:}

Khudolii Oleg: khudoli@hnpu.edu.ua; https://orcid.org/0000-0002-5605-9939; Department of Theory and Methodology of Physical Education, H. S. Skovoroda Kharkiv National Pedagogical University, Alchevskykh St, 29, Kharkiv, 61002, Ukraine. Iermakov Sergii: sportart@gmail.com; https://orcid.org/0000-0002-5039-4517; Department of Sports, Gdansk University of Physical Education and Sport, Kasimir Gorskogo St, 1, 80-336 Gdansk, Poland.

Ivashchenko Olha: ivashchenko@hnpu.edu.ua; https://orcid.org/0000-0002-2708-5636; Department of Theory and Methodology of Physical Education, H. S. Skovoroda Kharkiv National Pedagogical University, Alchevskykh St, 29, Kharkiv, 61002, Ukraine.

Nosko Mykola: chnpu@chnpu.edu.ua; http://orcid.org/0000-0001-9903-9164; Department of Pedagogy, Psychology and Methodology of Physical Education, T. H. Shevchenko National University “Chernihiv Colehium”, Hetman Polubotka St, 70, Chernihiv, 14000, Ukraine.

Cite this article as: Khudolii, O., Iermakov, S., Ivashchenko, O., \& Nosko, M. (2020). Strength Abilities: Modeling of Immediate and Delayed Training Effect of Strength Loads in Boys Aged 8 Years. Teoriâ ta Metodika Fizičnogo Vihovannâ, 20(4), $248-255$. https://doi.org/10.17309/tmfv.2020.4.08

Received: 12.11.2020. Accepted: 20.12.2020. Published: 25.12.2020

This work is licensed under a Creative Commons Attribution 4.0 International License (http://creativecommons.org/licenses/by/4.0). 